Öls über, ohne daß Anzeichen für eine Zersetzung des Öls im Destillationskolben zu beobachten waren. Das Destillat erwies sich als reiner, dimerer Metathioborsäure-

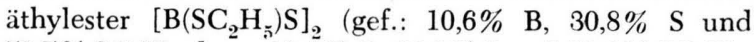
$58,7 \% \mathrm{SC}_{2} \mathrm{H}_{5}$, ber.: $10,4 \% \mathrm{~B}, 30,8 \% \mathrm{~S}$ und $58,8 \% \mathrm{SC}_{2} \mathrm{H}_{5}$; $M_{\text {gef. }}=201,3$ und $\left.209,6, M_{\text {ber. }}=208,0\right)$.

Wie daraus hervorgeht, ist die dimere Form (5a) des Metathioborsäure-äthylesters beständiger als die trimere Form (5b):

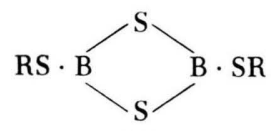

(a)

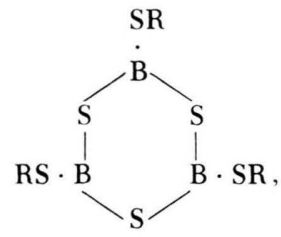

(b) während im Falle der freien Metathioborsäure die Stabilitätsverhältnisse gerade umgekehrt liegen 1 .

Der Ester ist in den sauerstoff-freien organischen Lösungsmitteln Benzol und Schwefelkohlenstoff leicht löslich, während er von den sauerstoff-haltigen Lösungsmitteln Aceton, Äther, Alkohol und Wasser mit zunehmender Heftigkeit zersetzt wird 6. Er besitzt einen unangenehmen, im Vergleich zum Orthothioborsäureester allerdings weit weniger intensiven Geruch. Eine Tendenz zur Disproportionierung in $\mathrm{B}_{2} \mathrm{~S}_{3}$ und $\mathrm{B}\left(\mathrm{SC}_{2} \mathrm{H}_{5}\right)_{3}$ besteht bis $150^{\circ}$ nicht.

6 Vgl. 4. Mitt.: E. Wiberg u. W. Sturm, Z. Naturforschg. $10 \mathrm{~b}, 108$ [1955].

\section{Über die Darstellung niederer Sulfide}

Von Ekkehard Gastinger

Centre National d'Etudes des Télécommunications, Paris

(Z. Naturforschg. 10 b, 115-116 [1955]; eingeg. am 17. Dez. 1954)

Erhitzt man In-Metall im $\mathrm{H}_{2} \mathrm{~S}$-Strom auf Rotglut, so färbt es sich oberflächlich gelb bis braun und überzieht sich zuletzt mit einer Schicht von $\mathrm{In}_{2} \mathrm{~S}_{3}{ }^{1}$. Es wurde gefunden, daß die Sulfidbildung an der Oberfläche unterbleibt, wenn man das Metall im $\mathrm{H}_{2} \mathrm{~S}$-Strom erhitzt und dabei gleichzeitig ein bestimmtes Vakuum aufrecht erhält. Dann verdampft das Metall als $\mathrm{In}_{2} \mathrm{~S}$, welches aus der Gasphase an einem Kühler niedergeschlagen werden kann. Dabei spielen sich offenbar folgende Reaktionen ab:

$$
\begin{aligned}
& 2 \mathrm{In}+3 \mathrm{H}_{2} \mathrm{~S}=\mathrm{In}_{2} \mathrm{~S}_{3}+\mathrm{H}_{2}, \\
& \mathrm{In}_{2} \mathrm{~S}_{3}+4 \mathrm{In}=3 \mathrm{In}_{2} \mathrm{~S},
\end{aligned}
$$

d. h. das zuerst gebildete $\operatorname{In}_{2} \mathrm{~S}_{3}$ reagiert mit dem überschüssigen Metall weiter $\mathrm{zu}^{2} \operatorname{In}_{2} \mathrm{~S}$, welches bei höherer Temperatur flüchtig ist. Bei geringer $\mathrm{H}_{2} \mathrm{~S}$-Konzentration im Gasraum reagiert das Gas mit dem Metall sofort nach:

$$
2 \mathrm{In}+\mathrm{H}_{2} \mathrm{~S}=\mathrm{In}_{2} \mathrm{~S}+\mathrm{H}_{2} .
$$

1 A. Thiel u. H. Ko els ch, Z. anorg. Chem. 66, 314 [1910].
Wichtig ist dabei, daß die Reaktionstemperatur genügend hoch und die $\mathrm{H}_{2} \mathrm{~S}$-Konzentration möglichst niedrig ist, damit der gesamte, durch den Zerfall des $\mathrm{H}_{2} \mathrm{~S}$ freiwerdende Schwefel vollständig umgesetzt wird. Andernfalls wird mit dem niederen Sulfid auch Schwefel an der Kühlfläche abgeschieden. Die Herabsetzung der $\mathrm{H}_{2} \mathrm{~S}$ Konzentration kann durch Vermischen mit einem inerten Gas erfolgen, am besten aber durch Herstellung eines Vakuums, wodurch gleichzeitig die Verdampfung der niederen Sulfide erleichtert wird. Sind diese besonders flüchtig, so kann man ohne Vakuum arbeiten. Man erhitzt das betreffende Element einfach im $\mathrm{H}_{2} \mathrm{~S}$-Strom. Das ist z. B. bei Ge möglich, welches bei höheren Temperaturen glatt nach der Gleichung

verdampft.

$$
\mathrm{Ge}+\mathrm{H}_{2} \mathrm{~S}=\mathrm{GeS}+\mathrm{H}_{2}
$$

Die neue Methode zur Herstellung von niederen Sulfiden ist einfacher als die bisher angewendeten. Da-

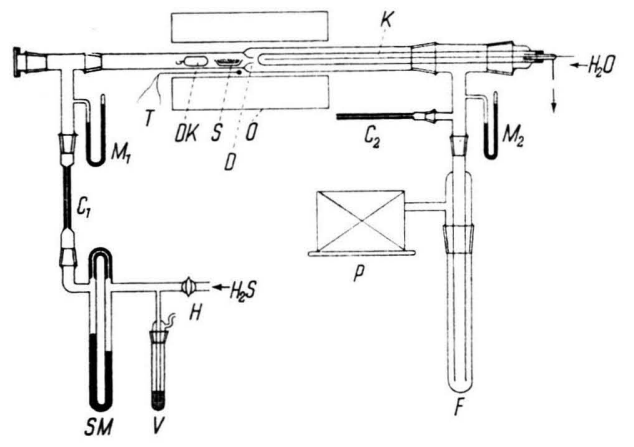

Abb. 1. Schema der Apparatur.

nach wurden die betreffenden Elemente mit ihren normalen Sulfiden im Hochvakuum erhitzt, z. B. 2

$$
\mathrm{Al}_{2} \mathrm{~S}_{3}+4 \mathrm{Al}=3 \mathrm{Al}_{2} \mathrm{~S} \text {. }
$$

Da es sich dabei in vielen Fällen um Reaktionen zwischen festen Stoffen handelt, sind die Umsetzungen mehr oder minder unvollständig. Auch die partielle Reduktion normaler Sulfide mit Wasserstoff führt häufig zu uneinheitlichen Produkten ${ }^{3}$. Nach der hier beschriebenen Methode werden sofort sehr reine Produkte erhalten. Auf diese Weise wurden größere Mengen $\mathrm{In}_{2} \mathrm{~S}, \mathrm{Ga}_{2} \mathrm{~S}$ und $\mathrm{GeS}$ hergestellt.

Abb. 1 zeigt das Schema einer Apparatur zur Erhitzung fester Stoffe oder von Schmelzen in einem Gasstrom im Vakuum. Das Gas tritt durch den Hahn H unter einem gewissen Überdruck ein, der durch die Höhe der Flüssigkeitssäule im Úberdruckventil V gegeben ist. Die Gasballastpumpe $\mathrm{P}$ saugt das Gas durch den Strömungsmesser SM, die Kapillare $C_{1}$, das Reaktionsrohr $R$, wel-

2 W. Klem m, K. Gei er sberger, B. S c ha ele r u. H. Mindt, Z. anorg. Chem. 255, 287 [1947].

3 A. Brukl u. G. Ortner, Monatsh. Chem. 56, 362 [1930]. 
ches sich im Ofen $\mathrm{O}$ befindet, und durch die Gasfalle F. Die Temperatur wird durch das außerhalb des Reaktionsrohres befindliche Thermoelement $\mathrm{T}$ gemessen. Das Reaktionsrohr trägt in der Mitte eine weite Düse $\mathrm{D}$ (Durchmesser 5-6 mm, Länge $10 \mathrm{~mm}$ ). In einem Abstand von ungefähr $10 \mathrm{~mm}$ vor der Düse befindet sich der Kühler K, hinter der Düse das Schiffchen S mit der reagierenden Substanz. Durch die Düse und den Diffusionskörper DK kann die Rückdiffusion der gasförmigen Reaktionsprodukte so weit unterdrückt werden, daß bei vorsichtiger Führung der Reaktion das entstehende niedere Sulfid praktisch nur am Kühlerende niedergeschlagen wird. Dadurch ist ein sauberes Arbeiten möglich. Das Reaktionsrohr und der Kühler bestehen aus Quarzglas, das Schiffchen aus Hartporzellan. Durch entsprechende Wahl der Kapillaren $\mathrm{C}_{1}$ und $\mathrm{C}_{2}$, wobei $\mathrm{C}_{2}$ auf einer Seite offen ist, kann man den Druck und die Volumgeschwindigkeit des Gases unabhängig voneinander regeln. Die erreichbaren Maximalwerte des Vakuums und der Strömungsgeschwindigkeit hängen von der Leistungsfähigkeit der Pumpe ab. Im vorliegenden Falle wurde eine Gasballastpumpe von Le ybold, Modell $S 50$, verwendet, welche einen Behälter von $1000 l$ Inhalt in $25 \mathrm{Min}$. auf ein Vakuum von $4 \cdot 10^{-3}$ Torr auspumpen kann. Die Drucke am Ein- und Ausgang des Reaktionsrohres können an den Manometern $\mathrm{M}_{1}$ und $\mathbf{M}_{2}$ abgelesen werden. Durch eigene Versuche wurde festgestellt, daß der Druckabfall im Reaktionsrohr annähernd linear ist, solange sich nicht zuviel gasförmige Reaktionsprodukte in der Zeiteinheit bilden. Die Ausgangsprodukte waren chemisch reine Substanzen der Fa. Fra n k e, Frankfurt a. M.

$\mathrm{Ga}$ und In ergaben bei $1000^{\circ} \mathrm{C}$ schwarze Sublimate. Der Druck betrug 10 Torr, die Strömungsgeschwindigkeit $0,4 \mathrm{ccm} / \mathrm{sec}$. Ge konnte ohne Vakuum bei $860^{\circ} \mathrm{C}$ schnell verdampft werden. Am Kühler bildeten sich schwarze Kristalle. In allen Fällen ergab die Analyse der Sublimate eine den Formeln $\mathrm{In}_{2} \mathrm{~S}, \mathrm{Ga}_{2} \mathrm{~S}$ und $\mathrm{GeS}$ entsprechende Zusammensetzung. Wie zunächst orientierende Versuche zeigten, kann auch $\mathrm{Al}$ und $\mathrm{Si}$ bei Temperaturen über $1100^{\circ} \mathrm{C}$ und wesentlich geringeren Drukken (kleiner als $5 \cdot 10^{-2}$ Torr) in Form von niederen Sulfiden verdampft werden. Die Untersuchungen sind noch im Gange. Über die Ergebnisse wird an anderer Stelle ausführlich berichtet werden.

\section{A New Phosphorus-Nitrogen Compound $\mathbf{P}_{3} \mathbf{N}_{21}$}

\author{
By Christoph Grundmann and Rudi Rätz \\ The Ohio State University Research Foundation, \\ Columbus 10, Ohio
}

(Z. Naturforschg. 10 b, 116-117 [1955]: eingeg. am 8. Nov. 1954)

Recent communications of Wiberg and $\mathrm{Michaud}{ }^{1}$ on the synthesis of new azides of the elements of the 1.-4. group of the periodical system prompt us to report

1 E. Wiberg u. H. Michaud, Z. Naturforschg. 9b. $495-502$ [1954]. the preparation of a new azido derivative of phosphorus. $\mathrm{P}_{3} \mathrm{~N}_{21}$. In the course of studies of the reactions of the polymeric phosphonitrilechlorides we found that the trimer (I) reacts very easily with six moles of sodium azide to form the trimeric phosphonitrile azide II, (2.2.4.4.6.6hexa-azido-2.4.6-triphospha-1.3.5-triazine), $\mathrm{P}_{3} \mathrm{~N}_{21}$.

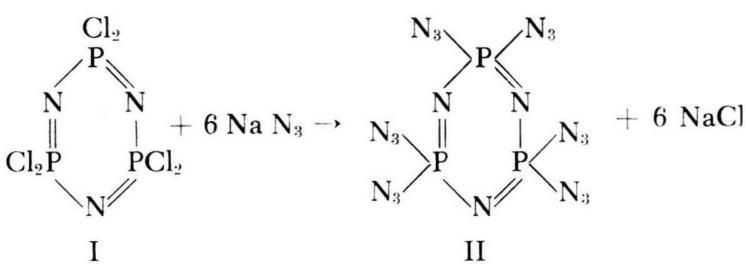

The hexa-azide is obtained as a colorless oil, heavier than water, insoluble in water, but miscible with all common organic solvents. It did not crystallize on storage at $-20^{\circ}$. When a small droplet is slowly heated up to $250^{\circ}$ at the plate of the $\mathrm{F}$ isher-Johns micro melting apparatus, it evaporates apparently without decomposition, but heating in an open flame or a moderate stroke with a hammer causes violent explosion accompagnied by a bright flash. The compound (II) is fairly stable against alkali; it is recovered unchanged after refluxing for 20 minutes with $10 \%$ aqueous hydroxide.

But acid hydrolysis decomposes the azide very readily, boiling with concentrated nitric acid dissolves it in a few minutes, and in this solution the phosphorus can be determined analytically by the usual methods.

The sensitivity of the compound has so far prohibited nitrogen and molecular weight determinations, but with consideration of the rather mild conditions of the synthesis and the relatively low volatility we feel justified to assume that it has a molecular structure analogous to its predecessor, the trimeric phosphonitrilechloride.

Trimeric phosphonitrilechloride $(0.696 \mathrm{~g}=1 / 500$ mole $)$ is dissolved in $6 \mathrm{ml}$ acetone in a three-necked $25 \mathrm{ml}$ flask. While passing in a stream of nitrogen, a solution of $1.56 \mathrm{~g}$ sodium azide, activated according to $\mathrm{Ne} 1 \mathrm{l} \mathrm{e} \mathrm{s}{ }^{2}$, in $8 \mathrm{ml}$ water is added dropwise under slight agitation. In an exathermic reaction the hexa-azide II ist immediately formed and separates in small oily droplets. The reaction is completed by warming the mixture for a short time to $45^{\circ}$. It is then let stand for two hours, $20 \mathrm{ml}$ of water is added, and the oil is extracted with ether. After drying over anhydrous sodium sulfate, the ether is removed in vacuo, and the hexa-azide II is obtained as a colorless oil in almost quantitative yield.

$$
\mathrm{P}_{3} \mathrm{~N}_{21} \text { : Calcd., P 24.01; Found, P 24.53. }
$$

The solution obtained by hydrolysis of the azide with nitric acid contained only traces of chlorine ion.

The greatest care is recommended in handling $\mathrm{P}_{3} \mathrm{~N}_{21}$, for while it is generally not very unstable, unforeseen explosions may occur. For example, after evaporation of an ethereal solution in vacuo, a heavy explosion followed an attempt to disconnect the ground joint of the flask

- J. Nelles, Ber. dtsch. chem. Ges. 65, 1345 [19.32]. 